JRSSEM 2021, Vol. 01, No. 5, 545 - 558

\title{
ANALYSIS OF FACTORS AFFECTING THE PROFITABIIITY IN CONSUMER GOODS SECTOR COMPANIES LISTED ON THE INDONESIA STOCK EKCHANGE IN 2015-2020 PERIOD
}

\author{
Dwi Verasasti Tarihoran ${ }^{1}$ \\ Endri Endri ${ }^{2}$ \\ 1, 2 Magister Management, University of Mercu Buana, Indonesia \\ e-mail:dwiverasasti94@gmail.com ${ }^{1}$, endri@mercubuana.ac.id ${ }^{2}$ \\ *Correspondence: dwiverasasti94@gmail.com ${ }^{1}$
}

Submitted: 4 December 2021, Revised: 11 December 2021, Accepted: 14 December 2021

\begin{abstract}
This study examines factors that affect profitability in the consumer goods sector listed on the Indonesia Stock Exchange (IDX) for the 2015-2020 period. In this study, the population are consumer goods sector companies listed on the Indonesia Stock Exchange for the 2015-2020 period. The technique used purposive sampling that obtained as many as 19 companies for the research objects. The independent variable in this study is Return On Assets (ROA). In contrast, the independent variables are Current ratio (CR), Debt to equity ratio (DER), Total Asset Turnover (TATO), Working Capital (WC), Sales Growth (Grow), Size Company (Firm Size), World Oil Price (Oil Price), and Exchange Rate. The test method to determine the effect of the independent variable on the dependent variable is the panel data regression analysis method which is processed using $\mathrm{E}$ VIEWS 12. Based on the results of simultaneous research, it is known that CR, TATO, GROW have a significant positive effect on profitability (ROA), WC and FIRM Size has a negative and significant impact on profitability (ROA), while DER, Oil Price and Exchange Rate (Exchange) do not have a substantial effect on profitability (ROA).
\end{abstract}

Keywords: profitability; current ratio (cr); debt to equity ratio (der); total asset turnover (tato); working capital (wc); 


\section{INTRODUCTION}

The Ministry of Industry noted that generally the realization of investment in the industrial sector of Indonesia has increased in 2015-2019. In the fourth quarter of 2019, the industrial realization reached 208 trillion, but the consumer goods industry sector declined in 2019 at rate of $26.7 \%$. Along this matter that world oil prices are a very influential factor in the Indonesian industry. The fallen prices of oil will pose a risk to the current account balance. The companies of consumer goods sector have recently become the most preference sector by several investors. It was recorded based on the survey of $B I$ in August 2019, it stated that the consumer confidence index (IKK) was in the optimistic zone at $123.1 \%$ (BPS, 2019).

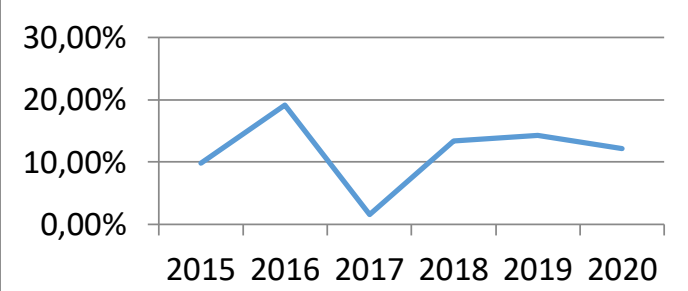

Figure 1. The Growth in Profitability Ratio of Consumer Goods Sector 2015-2020

From the data above, we can determine that the growth in the profitability ratio of the consumer goods sector in 2015-2020 has a very volatile trend. From the graph, the researcher wants to find out what factors can influence this ratio. Profitability is a measurement of the company's efficiency in managing assets to earn a maximum profit. Profitability provides an overview in carrying out its profit of a company (Warrad \& Al Omari, 2015). Return on Assets (ROA) is a financial comparison that can measure industry profitability skills, it describes how to get a net profit to the total assets owned.

\section{PROFITABILITY RATIO}

Profitability comparison defines as a comparison that can evaluate the industry to earn a profit. It measures the level of management performance in obtaining profit for the company. (Kasmir, 2016) stated that the profitability ratio is the success of company to produce a profit.

\section{Return on Assets (ROA)}

Return On Assets (ROA) is known as Return On Investment (ROI). This comparison is used for management measurement to invest in obtaining a profit. The greater its comparison, the more it shows the success of industry in using assets in the company.

$$
\begin{aligned}
& \text { Return On Asset } \\
& =\frac{\text { Earning after interst and tax }}{\text { Total Assets }}
\end{aligned}
$$

\section{Return on Equity (ROE)}

Return on Equity (ROE) is known as the profitability of its own capital, it means ratio that used for measuring profits. This ratio compares net profit after tax with its own capital. The results of this ratio show the efficiency of the application of company capital. The bigger this comparison, the stronger the company ownership, and vice versa.

$$
\begin{aligned}
& \text { Return On Equity } \\
& =\frac{\text { Earning after interst and tax }}{\text { Equity }}
\end{aligned}
$$

\section{Agency Theory}

Agency theory is the contractual relationship between managers or agents with shareholders. The relationship embodies a contract that conveys each of their rights and obligations. Shareholders (principals) are providers of funds and 
547 | Analysis of Factors Affecting The Profitability in Consumer Goods Sector Companies Listed on The Indonesia Stock Exchange in 2015-2020 Period

facilities for executing the company, while managers (agents) are agents who have responsibility given by the principal (optimum (Wirahadi Ahmad \& Septriani, 2008) said that agency theory is a contact alignment used for the interests of shareholders and managers.

\section{Pecking Order Theory}

Packing order theory discusses industry considerations in deciding the fund of company capital. This case explains that the company tends to explore the use of the company's internal capital, it expected that the company will not expose it to outside parties. External sources of funds become consideration for the company, the first is the consideration of costs in issuing shares such as issuance costs and bond costs. In addition, this can impact on the decline in the price of the old stock. The second consideration is that investors will evaluate the company as disreputable, this is caused by a decline in stock prices (Sutriana et al., 2021)

\section{Signaling Theory}

Signal theory (Signaling Theory) was started in 1973 by Michael Spence in his research entitled Job Market Signaling (Karasek III \& Bryant, 2012)In this study, Spence assumes labor market that measure the productivity capability. From these results, Spance established labour standards in the form of signals to make decisions for business people/investors.

\section{Trade Off Theory}

The theory was originally proposed by Modigliani and Miller in 1963. His article entitled Corporate Income Tax on the Cost of Capital, discusses the calculation of individual taxes. This theory developed with the MM-2 model. It was elaborated by
(Brigham \& Ehrhardt, 2005), it explains that the company's debt and equity should describe the balance between costs and revenues earned by the company.

\section{Liquidity Ratio}

Liquidity Ratio is a ratio that determines industrial skills to pay its shortterm debt obligations. The ratio between short-term obligations and short term of fund sources is meant to pay the shortterm obligations (Uremadu et al., 2012). Liquidity Ratio can also be defined as the short-term ability of the industry to observe current assets to current liabilities (Islam et al., 2014). Current Ratio is a ratio used to understand industrial skills to pay shortterm debt obligations (Kasmir, 2016)The calculation of the current ratio is carried out through a comparison between the total current assets and total current liabilities.

$$
\text { Current Ratio }=\frac{\text { current assets }}{\text { current liabilities }}
$$

1. The cash ratio is a ratio used to compare current assets that are really liquid with their short-term liabilities (Kasmir, 2016)The cash ratio indicator can measure all industrial assets and the total liquid money in the banking industry to its operational or payment of short-term debt.

Cash Ratio $=\frac{\text { Cas Or Cas equivalent }}{\text { Current Liabilities }}$

\section{Activity Ratio}

Activity Ratio is a ratio to measure the company's efficiency of assets application in obtaining a profit. This ratio is also often applied in understanding the industry's work over time concerning company's horizontal analysis.

\section{Total Asset Turnover Ratio}

This ratio is a ratio to determine 
wealth activity when getting a profit. A ratio that compares net sales and average total wealth.

Total Asset Turnover

$$
=\frac{\text { net sales }}{\text { average total assets }}
$$

\section{Working Capital Turnover Ratio}

This ratio is a ratio to determine the level of company skills applying working capital (cash) to generate sales/profit levels.

Working capital turnover

$$
=\frac{\text { sales }}{\text { average working capital }}
$$

\section{Laverage Ratio}

Laverage ratio is a ratio to determine industrial skills in spending company debt to earn profits (Bener et al., 2013)This ratio also indicates the industry's financial skills to pay in short or long term financial obligations.

\section{Debt to equity ratio (DER)}

$D E R$ is a ratio for the measurement between capital funds and debt (creditors) (Schlumberger et al., 2015)This ratio is also used to assess the percentage of industrial capital which include to a debt guarantee.

$$
\text { ebt to equity ratio }=\frac{\text { Total debt }}{\text { Total equity }}
$$

\section{Debt to Asset Ratio (DAR)}

DAR is a ratio to determine the percentage of the industry that is paid out of debt. In addition, this also shows the ratio between the available funds from investors (shareholders) and creditors (Schlumberger et al., 2015)

$$
\text { Debt to asset ratio }=\frac{\text { Total debt }}{\text { Total Asset }}
$$

Working Capital Turn Over

Working capital is cash company assets stored in bank accounts, the other assets is expected to pay off the company operational (Harmoni, 2021) Simply, working capital is defined as the financing of daily operational funds. If the company has a high working capital, it can be concluded that the industry has good financial results. To measure working capital can be done as follows:

Working Capital Turnover

$=\frac{\text { Penjualan }}{\text { Current Asset }- \text { Current Liabilities }}$

In general, working capital can be calculated in the form of a ratio, with the following formula:

Working Capital Ratio

$$
=\frac{\text { Current Asset }}{\text { Current Liabilities }}
$$

\section{Sales Growth}

Company growth is useful for measuring the increase in sales or profits in an industry. Sales are the main source of company income. Sales growth can be defined by the more of stable and enhance company's sales followed by operational costs or other costs that can be controlled by the company (Putri, 2015)

$$
\text { sales growth }=\frac{\text { Sales } t-\text { Sales } t-1}{\text { Sales } t-1}
$$

\section{Firm Size (Firm Size)}

Firm size is measured by the total assets, total sales, and stock prices in a company (Indrawan et al., n.d.) The total assets owned by the industry is expected to obtain high profits and sales levels.

Firm size (Size it)

\section{World Oil Price}

$$
=\log \text { Total Asset it }
$$

This price is measured using the 
549 | Analysis of Factors Affecting The Profitability in Consumer Goods Sector Companies Listed on The Indonesia Stock Exchange in 2015-2020 Period

world oil market spot. West Taxes Intermediate (WTI) often referred to as light sweet that is a benchmark for world crude oil prices (Antono et al., 2019) said that West Texas Intermediates (WTI) trades high-quality crude oil and it has a higher price than Brent Blend and OPEC oil.

\section{Exchange Rate}

The exchange rate indicates the total value of the domestic currency in conducting transactions to obtain a unit (Sukino, 2002). Demand and supply are factors that can affect the movement of an exchange rate (Rusbariand et al., 2012) Marto and Munawar (2014) stated that the exchange rate can affect the amount of sales, expenses, profits, and prosperity, indeed the exchange rate also affects international problems that cause risks to the company.

\section{Hypothesis Formulation}

There a lot of hypothesis submission in the following research regarding the problems that occur in the Metals and Minerals of the mine industry, such as:

H1: Current Ratio (CR) has a positive effect on Return On Assets (ROA).

H2: Total Assets Turnover (TATO) has a positive effect on ROA

H3: Debt to Equity Ratio (DER) has a positive effect on ROA

H4: Working Capital Turn Over has a positive effect on ROA.

H5: Sales Growth has a positive effect on ROA

H6: Firm size has a positive effect on ROA

H7: World oil prices have a positive effect on ROA

H8: Exchange rate has a positive effect on ROA

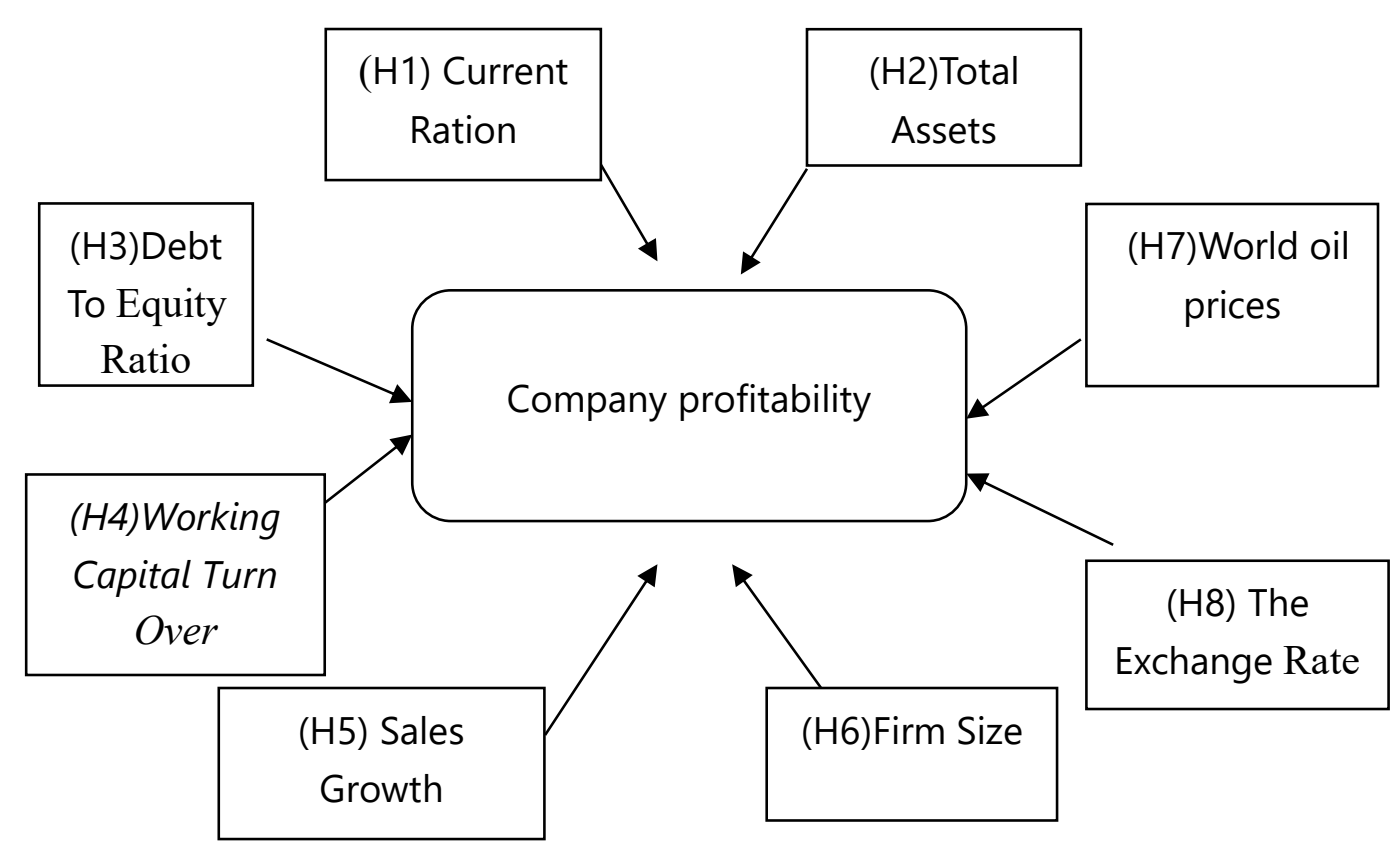

Figure 2. Study Framework 
This analysis is a test that is often used before analyzing panel data regression. The tests have various variables in obtaining the whole description in the study. The variables used for this research include: (1) the dependent variable, namely ROA, and (2) the independent variable, namely (a) $C R$, (b) DER, (c) TATO. (d) Working Capital Turn Over, (e) Sales Growth, (f) Firm Size, (g) Oil price, and (h) Exchange Rate. An overview of each variable during the study period is described in table 1.

Table 1. Descriptive Statistical Analysis of Dependent and Independent Variables.

\begin{tabular}{lccccccccc} 
& ROA & CR & DER & TATO & WC & GROW & SIZE & OP & KURS \\
\hline Mean & 0.14 & 3.53 & 0.70 & 1.29 & 4.26 & 0.02 & 22.12 & 6.94 & 9.54 \\
\hline Median & 0.11 & 2.48 & 0.55 & 1.12 & 3.65 & 0.02 & 21.80 & 6.96 & 9.54 \\
\hline Maximum & 0.58 & 15.82 & 3.15 & 3.11 & 62.03 & 1.02 & 29.29 & 7.13 & 9.58 \\
\hline Minimum & 0.01 & 0.15 & 0.07 & 0.44 & -14.91 & -1.00 & 13.39 & 6.70 & 9.51 \\
\hline Std. Dev. & 0.12 & 3.14 & 0.61 & 0.60 & 9.35 & 0.21 & 5.82 & 0.15 & 0.02 \\
\hline Observations & 90 & 90 & 90 & 90 & 90 & 90 & 90 & 90 & 90
\end{tabular}

Source: Output E-Views 12.0 (processed by the researcher, 2021)

MATERIALS AND METHODS

\section{Chow Test Results}

The Chow test is used to determine which of the Common Effect models or Fixed Effect models are suitable for panel

Table 2. The Results of Chow Test

Redundant Fixed Effects Tests

Equation: Untitled

Test cross-section fixed effects

\begin{tabular}{lcrr}
\hline Effects Test & Statistic & d.f. & Prob. \\
\hline Cross-section F & 4.776884 & $(14,67)$ & 0.0000 \\
\hline Cross-section Chi-square & 62.300175 & 14 & 0.0000 \\
\hline \hline
\end{tabular}

Sumber: Output E-Views 12.0 (processed by the researcher, 2021)

\section{Hausman Test Results}

Hausman test is conducted to determine which one is better between Fixed effect model or Random Effect model for panel data estimation. The results of the data estimation. This test can be carried out with the $\mathrm{F}$ or Chi-square statistical test. The results of Chow test in the research can be observed in table 5 .

Hausman test in this study can be observed through table 3 . 
Table 3.The Results of Hausman Test

Correlated Random Effects - Hausman Test

Equation: Untitled

Test cross-section random effects

\begin{tabular}{lrrr}
\hline Test Summary & Chi-Sq. Statistic & Chi-Sq. d.f. & Prob. \\
\hline \hline Cross-section random & 0.000000 & 8 & 1.0000 \\
\hline
\end{tabular}

Source : Output E-Views 12.00 (processed by the researcher, 2021

Table 3 shows the results of the Hausman test using the E-Views software, and the chi-square value exceeds $=0.05$ (5\%) which is 1,0000 . Therefore, the test can be concluded that $\mathrm{HO}$ is accepted and $\mathrm{H} 1$ is rejected. This means the Random Effect Model is better used in estimating panel data regression than the Fixed Effect Model in this study.

\section{Lagrange Multiplier Test Results}

The Lagrange Multiplier test is carried out to determine which of the Common Effect models or Random Effect Models is the more suitable for panel data estimation. The results of the Lagrange Multiplier test for this research can be observed in table 7 .

Table 4. The Results of Lagrange Multiplier Test

Correlated Random Effects - Hausman Test

Equation: Untitled

Test cross-section random effects

\begin{tabular}{lrrr}
\hline Test Summary & Chi-Sq. Statistic & Chi-Sq. d.f. & Prob. \\
\hline Cross-section random & 0.000000 & 8 & 1.0000 \\
\hline
\end{tabular}

Source: Output E-Views 12.0 (processed by the researcher, 2021)

\section{Lagrange Multiplier Test Results}

The Lagrange Multiplier test is carried out to determine which of the Common Effect models or Random Effect Models is the more suitable for panel data estimation. The results of the Lagrange Multiplier test for this research can be observed in table 7 .

Table 4. The Results of Lagrange Multiplier Test

Null hypotheses: No effects

Alternative hypotheses: Two-sided (Breusch-Pagan) and one-sided (all others) alternatives

\begin{tabular}{lccc}
\hline & \multicolumn{3}{c}{ Test Hypothesis } \\
\hline Breusch-Pagan & Cross-section & Time & Both \\
\hline & 29.36348 & 0.006456 & 29.36994 \\
\hline Honda & $(0.0000)$ & $(0.9360)$ & $(0.0000)$ \\
\hline & 5.418808 & 0.080348 & 3.888491 \\
\hline King-Wu & $(0.0000)$ & $(0.4680)$ & $(0.0001)$ \\
\hline & 5.418808 & 0.080348 & 2.848761 \\
\hline
\end{tabular}




\begin{tabular}{lccc}
\hline \hline Standardized Honda & 6.594952 & 1.259301 & 1.894750 \\
\hline & $(0.0000)$ & $(0.1040)$ & $(0.0291)$ \\
\hline Standardized King-Wu & 6.594952 & 1.259301 & 1.055247 \\
\hline \multicolumn{5}{c}{$(0.0000)$} & $(0.1040)$ & $(0.1457)$ \\
\hline \multicolumn{5}{c}{--} & -- & 29.36994 \\
\hline${ }^{*}$ Mixed chi-square asymptotic critical values: & $(<0.01)$ \\
\hline \multicolumn{5}{c}{7.289} \\
\hline $5 \%$ & 4.321 \\
\hline $5 \%$ & 2.952 \\
\hline
\end{tabular}

Source: Output E-Views 12.0 (processed by the researcher, 2021)

Table 4 shows the results of the Lagrange Multiplier test using E-Views software, and the results of the BreuschPagan LM-test calculation are 29.36994 and the $p$-value $(0.0000)$ is not greater than $=0.5$ (5\%). So, we conclude that the Random Effect model is better than the Common Effect model for estimating the panel data regression.

\section{Fit Test Model}

\section{Significance Test Model (Test $-\mathrm{F}$ )}

Examining to the results of statistical data processing shown in table 12, it can be observed that the Prob value (F-Statistic) is 0.0000 not exceeding $=0.05$, which means that $\mathrm{H} 0$ is rejected and $\mathrm{H} 1$ is accepted. This indicates that the independent variables of CR, DER, TATO, Working Capital, Sales Growth, Firm Size, World Oil Price and Exchange Rate concurrent significant effect on the ROA of the consumer goods sector industry in this study.

\section{Independent Variable Significance Test (t-test)}

1. Current Assert (CR) has a positive coefficient value of 0.289572 with a tcount value of 2.740461 and a sig. value of 0.0075 , it is smaller than 0.05 . This means that the $C R$ variable is proven to have a positive and significant impact on ROA in the consumer goods sector industry listed on the IDX for the 20152020 period.

2. Debt to Equity Ratio (DER) has a positive coefficient value of 0.156588 with a $t$ count value of 1.411721 and a sig. value of 0.1619 , it is greater than 0.05 . This means that the DER variable is proven to be insignificant to ROA in the consumer goods sector industry on the IDX for the 2015-2020 period.

3. Total Asset Turnover (TATO) has a positive coefficient value of 0.1201160 with a t-count value of 2.985848 and a sig. value of 0.0037 , it is greater than 0.05. This means that the TATO variable is proven to have a positive effect and sig. to ROA in the consumer goods sector industry on the IDX for the 20152020 period.

4. Working Capital turnover (WC) has a positive coefficient value of -0.016154 with a t-count value of -6.394667 and a sig. value of 0.0000 , it is greater than 0.05 . This means that the WC variable is proven to have a negative and 
significant effect on ROA in the consumer goods sector industry on the IDX for the 2015-2020 period.

5. Sales Growth has a positive coefficient value of 0.201478 with a t-count value of 2.075972 and a sig. value of 0.0411 , it is smaller than 0.05 . This means that the GROW variable is proven to have a positive and significant impact on ROA in the consumer goods sector industry on the IDX for the 2015-2020 period.

6. Firm Size has a positive coefficient value of -0.025331 with a $t$-count value of 3.360939 and a significance value of 0.0012 , it is greater than 0.05 . This means that the Firm Size variable is proven to have a negative and significant effect on ROA in the consumer goods sector industry listed on the IDX for the 2015-2020 period.

7. World Oil Price has a positive coefficient value of 0.168182 with a $t$-count value of 1.090413 and a sig. value of 0.2788 , it is greater than 0.05 . This means that the Oil Price variable is proven to be insignificant to ROA in the consumer goods sector industry listed on the IDX for the 2015-2020 period.

8. The exchange rate has a positive coefficient value of 0.446441 with a tcount value of 0.467834 and $a$ significant value of 0.6412 , it is greater than 0.05 . It means that the exchange rate variable is proven to be insignificant to ROA in the consumer goods sector industry on the IDX for the 2015-2020 period.

\section{RESULTS AND DISCUSSION}

The Effect of Current Ratio (CR) on

\section{Return On Assets (ROA)}

Based on the results of the panel data regression test of the best model usage, the Random Effect model shows that $C R$ has a positive and significant effect on ROA. The results of this study are supported by previous researches has conducted by (Sekti, 2017), (Sharon, 2020), (Lubis \& Rahmawati, 2019), (ENDRI et al., 2020), and ( $\mathrm{Ng}$ et al., 2020) which said that $\mathrm{CR}$ has a positive and significant impact on industry profitability, that is ROA.

\section{The Effect of Debt to Equity Ratio (DER) on Return on Assets (ROA)}

It refers to the results of panel data regression testing that uses the best model usage, namely the Randem Effect model, it indicates that DER does not have a significant effect on company profitability (ROA). The results of this study show that DER has no effect on ROA. It supported by previous researchers of (Putra \& Lestari, 2016), (Sari \& Budiasih, 2014), (Angelina et al., 2020), (Wulantika et al., 2018), (ENDRI et al., 2020), (Endri et al., 2021), who revealed that DER has no effect on ROA.

\section{The Effect of Total Asset Turnover (TATO) on Return on Assets (ROA)}

This study refers to the results of panel data regression tests of the best model usage, namely the Randem Effect model, it indicates that TATO has a positive and significant impact on company profitability (ROA). It supported by previous researchers of (Kurniawati et al., 2020). (Ruroh \& Rahmawati, 2016), (Hakim et al., 2020), (ENDRI et al., 2020), They stated that Total Asset Turnover has a positive and significant effect on the company's profitability Return On Assets (ROA).

The Effect of Sales Growth on Return on 


\section{Assets (ROA)}

It refers to the results of the panel data regression test of the best model usage, namely the Random Effect model, it indicates that sales growth has a significant positive effect on ROA. It supported by previous researches conducted by (Suryaputra, 2016), (R. Yulius et al., 2016), (Nyoman \& Gana, 2018), (Utami \& Prasetiono, 2016), (Marlapa, 2020), (Aminuddin et al., 2021), (ENDRI et al., 2020) the results reveals that sales growth has a positive and significant impact on company profitability.

\section{The Effect of Firm Size on Return on Assets (ROA)}

It refers to the results of panel data regression tests of the best model usage, namely the Randem Effect model, it indicates that company size has a negative and significant effect on ROA. It supported by previous researches conducted by (Suryaputra, 2016), (R. Yulius et al., 2016) they said that the size of the industry has a negative and significant effect on profitability (ROA).

\section{The Effect of World Oil Price (Oil Price) on Return on Assets (ROA)}

It refers to the results of panel data regression tests of the best model usage, namely the Randem Effect model, it indicates that World Oil Prices do not have a significant effect on company profitability (ROA). It supported by previous researches (Prasetyo \& Darmawan, 2017), stated that the world oil price (Oil price) has no effect on profitability (ROA).

\section{The Effect of Exchange Rate (Exchange Rate) on Return on Assets (ROA)}

It refers to the results of panel data regression tests of the best model usage, namely the Randem Effect model, it indicates that the exchange rate does not have a significant effect on the company's profitability (ROA). It supported by previous researches of (Prasetyo \& Darmawan, 2017), (Ben-Ari et al., 2017), (Adiyadnya et al., 2016) they stated that the exchange rate does not have a significant effect on profitability (ROA).

\section{CONCLUSIONS}

Based on the results of the analyzing data and explanations that have been carried out, it concludes that $C R$ has a positive and significant impact on the profitability of the consumer goods sector industry for the 2015-2020 period. DER does not have a significant effect on the profitability of the consumer goods sector industry for the 2015-2020 period. TATO has a positive and significant impact on the profitability of the consumer goods sector industry for the 2015-2020 period. Working Capital Turnover has a negative and significant impact on the profitability of the consumer goods sector industry for the 2015-2020 period. Sales growth has a positive and significant impact on the profitability of the consumer goods sector industry for the 2015-2020 period. Firm Size has a negative and significant impact on the profitability of the consumer goods sector industry for the 2015-2020 period. The world oil price does not have a significant effect on the profitability of the consumer goods sector industry for the 2015-2020 period. The exchange rate does not have a significant effect on the profitability of the consumer goods sector industry for the 2015-2020 period. 
555 | Analysis of Factors Affecting The Profitability in Consumer Goods Sector Companies Listed on The Indonesia Stock Exchange in 2015-2020 Period

\section{REFERENCES}

Adiyadnya, I. N. S., Artini, L. G. S., \& Rahyuda, H. (2016). Pengaruh Beberapa Variabel Ekonomi Makro Terhadap Profitabilitas dan Return Saham Pada Industri Perbankan di BEI. E-Jurnal Ekonomi Dan Bisnis Universitas Udayana, 5(8), 26012602.

Aminuddin, H. B., Jiao, N., Jiang, Y., Hong, J., \& Wang, W. (2021). Effectiveness of smartphone-based self-management interventions on self-efficacy, selfcare activities, health-related quality of life and clinical outcomes in patients with type 2 diabetes: A systematic review and meta-analysis. International Journal of Nursing Studies, $\quad 116,103286$. https://doi.org/10.1016/j.jinurstu.201 9.02 .003

Angelina, C., Sharon, S., Lim, S., Lombogia, J. Y. R., \& Aruan, D. A. (2020). Pengaruh Current Ratio, Debt to Equity, Perputaran Kas dan Total Asset TurnOver (TATO) Terhadap Profitabilitas pada Perusahaan Food \& Beverages yang terdaftar di Bursa Efek Indonesia. Owner: Riset Dan Jurnal Akuntansi, 4(1), 16-27. https://doi.org/10.33395/owner.v4i1.1 78

Antono, Z., Jaharadak, A., \& Khatibi, A. (2019). Analysis of factors affecting stock prices in mining sector: Evidence from Indonesia Stock
Exchange. Management Science Letters, 9(10), 1701-1710. http://dx.doi.org/10.5267/j.msl.2019. 5.018

Ben-Ari, A., Chansky, H., \& Rozet, I. (2017). Preoperative opioid use is associated with early revision after total knee arthroplasty: a study of male patients treated in the veterans affairs system. JBJS, 99(1), $1-9$. 10.2106/JBJS.16.00167

Bener, A., Yousafzai, M. T., Darwish, S., AlHamaq, A. O. A. A., Nasralla, E. A., \& Abdul-Ghani, M. (2013). Obesity index that better predict metabolic syndrome: body mass index, waist circumference, waist hip ratio, or waist height ratio. Journal of Obesity, 2013.

https://doi.org/10.1155/2013/26903 8

Brigham, E. F., \& Ehrhardt, M. C. (2005). Financial management: Theory and practice, 11e. Thomson South Western.

Endri, E., SARI, A. K., BUDIASIH, Y., YULIANTINI, T., \& KASMIR, K. (2020). Determinants of profit growth in food and beverage companies in Indonesia. The Journal of Asian Finance, Economics, and Business, 7(12), 739-748. https://doi.org/10.13106/jafeb.2020. vol7.no12.739

Hakim, R., Ritonga, M., \& Susanti, W. (2020). Implementation of Contextual 
Teaching and Learning in Islamic

Education at Madrasah Diniyah. Jour of Adv Research in Dynamical \& Control Systems, 12.

Harmoni, H. (2021). Pengaruh Pertumbuhan Penjualan Dan Likuiditas Terhadap Harga Saham Pada Perusahaan Manufaktur Sektor Aneka Industri Yang Tedaftar Di Bursa Efek Indonesia Periode 2015-2019. 021008 Universitas Tridinanti Palembang.

Indrawan, D. A., Meli Nuraini, S. S. W., Sururi, U. T., \& Mulyati, Y. (n.d.). Factors Affect Tax Avoidance (Empirical Study On The Mining Sector And Component Listed In The Indonesia Stock Exchange Throughout 2016-2019). Turkish Journal of Physiotherapy and Rehabilitation, 32, 3.

Islam, M. J., Hakim, M. A., Hanafi, M. M., Juraimi, A. S., Aktar, S., Siddiqa, A., Rahman, A. K. M. S., Islam, M. A., \& Halim, M. A. (2014). Hydrogeochemical quality and suitability studies of groundwater in northern Bangladesh. Journal of Environmental Biology, 35(4), 765.

Karasek III, R., \& Bryant, P. (2012). Signaling theory: Past, present, and future. Academy of Strategic Management Journal, 11(1), 91.

Kasmir, S. (2016). The Mondragon cooperatives and global capitalism: A critical analysis. New Labor Forum, 25(1), 52-59.
https://doi.org/10.1177\%2F1095796 015620424

Kurniawati, R. P., Gunawan, I., \& Marlina, D. (2020). Mathematic Literation Abilities Based on Problem Solving Abilities in First Class 4 of Elementary School. 2nd Early Childhood and Primary Childhood Education (ECPE 2020), 186-192.

Lubis, A. H., \& Rahmawati, E. (2019). Literature-circles-based cooperative writing: From the perceptions of Indonesian university EFL learners with writing anxiety. Journal of Asia TEFL, 16(4), 1422.

Marlapa, E. (2020). Quality of Service and Community Disciplinary Officer with Quality Products for Variable Interviening Customer Satisfaction: National Savings Bank Syariah Branch Bogor Regency Cigombong. International Review of Management and Marketing, 10(4), 132.

Ng, D. L., Goldgof, G. M., Shy, B. R., Levine, A. G., Balcerek, J., Bapat, S. P., Prostko, J., Rodgers, M., Coller, K., \& Pearce, S. (2020). SARS-CoV-2 seroprevalence and neutralizing activity in donor and patient blood. Nature Communications, 11(1), 1-7.

Nyoman, M. I. B., \& Gana, K. D. G. A. (2018). Folktales As Meaningful Cultural And Linguistic Resources To Improve Students'reading Skills. Lingua Scientia, 25(2), 83-88. http://dx.doi.org/10.23887/ls.v25i2.1 
557 | Analysis of Factors Affecting The Profitability in Consumer Goods Sector Companies Listed on The Indonesia Stock Exchange in 2015-2020 Period

8827

Prasetyo, D. A., \& Darmawan, A. (2017). Pengaruh Risiko Inflasi, Risiko Suku Bunga, Risiko Nilai Tukar dan Leverage terhadap Profitabilitas (Studi pada Perusahaan Sub Sektor Makanan dan Minuman yang Terdaftar di Bursa Efek Indonesia Tahun 2012-2016). Jurnal Administrasi Bisnis, 50(3), 48-56.

Putra, A. A. N. D. A., \& Lestari, P. V. (2016). Pengaruh kebijakan dividen, likuiditas, profitabilitas dan ukuran perusahaan terhadap nilai perusahaan. Udayana University.

PUTRI, T. D. (2015). Penerapan Electronic Government (E-Gov) Pemerintah Provinsi Riau Sebagai Media Komunikasi Untuk Mewujudkan Transparansi Publik.

Ruroh, F. M., \& Rahmawati, D. (2016). Pengaruh Pergantian Manajemen, Kesulitan Keuangan, Ukuran Kap, dan Audit Delay terhadap Auditor Switching Studi Kasus pada Perusahaan Manufaktur yang Terdaftar di Bursa Efek Indonesia Tahun. Nominal: Barometer Riset Akuntansi Dan Manajemen, 5(2), 6880.

http://dx.doi.org/10.21831/nominal.v $5 i 2.11726$

Rusbariand, S. P., Masodah, R., \& Herawati, S. (2012). Analisis pengaruh tingkat inflasi, harga minyak dunia, harga emas dunia, dan kurs rupiah terhadap pergerakan jakarta islamic index di bursa efek indonesia. Prosiding Seminar Nasional, 1, 724-740.

Sari, N. M. V., \& Budiasih, I. (2014). Pengaruh debt to equity ratio, firm size, inventory turnover dan assets turnover pada profitabilitas. E-Jurnal Akuntansi Universitas Udayana, 6(2), 261-273.

Schlumberger, M., Tahara, M., Wirth, L. J., Robinson, B., Brose, M. S., Elisei, R., Habra, M. A., Newbold, K., Shah, M. H., \& Hoff, A. O. (2015). Lenvatinib versus placebo in radioiodinerefractory thyroid cancer. New England Journal of Medicine, 372(7), 621-630. 10.1056/NEJMoa1406470

Sekti, B. (2017). Pengaruh Current Ratio, Debt Ratio, Total Asets Turnover, Return on Assets, Return on Equity, Current Liability To Total Liability, Dan Fixed Asset To Total Assets Terhadap Kesehatan Perusahaan Manufaktur Di Indonesia (Studi Pada Perusahaan Manufakt. Jurnal Ekonomi Universitas Esa Unggul, 8(01).

Sharon, T. (2020). Blind-sided by privacy? Digital contact tracing, the Apple/Google API and big tech's newfound role as global health policy makers. Ethics and Information Technology, 1-13.

Sukino, R. (2002). Analisa rasio keuangan pada Mosquito Coil Group. Universitas Pelita Harapan. 
Suryaputra, G. (2016). Pengaruh Manajemen Modal Kerja,

Pertumbuhan Penjualan dan Ukuran Perusahaan Terhadap Profitabilitas Pada Perusahaan Properti dan Real Estate Yang Terdaftar di Bursa Efek Indonesia (BEI) Tahun 2010-2014. Business Accounting Review, 4(1), 493504.

Sutriana, A., Sayuti, A., Panjaitan, B., TR, T. A., Tunnisa, A. F., Melia, J., Siregar, T. N., Hafizuddin, H., \& Aliza, D. (2021). The Effectiveness of Lugol on the Increasing of Pregnancy Rate in Aceh Cow with Endometritis. Jurnal Agripet, 21(2), 187-191.

Uremadu, S. O., Egbide, B.-C., \& Enyi, P. E. (2012). Working capital management, liquidity and corporate profitability among quoted firms in Nigeria evidence from the productive sector. International Journal of Academic Research in Accounting, Finance and Management Sciences, 2(1), 80-97.

Utami, R. B., \& Prasetiono, P. (2016). Analisis Pengaruh TATO, WCTO, Dan DER Terhadap Nilai Perusahaan Dengan ROA Sebagai Variabel Intervening (Studi pada Perusahaan Manufaktur yang Terdaftar di Bursa Efek Indonesia Periode Tahun 2009-2013). Diponegoro Journal Of Management, 5(2), 105-118.

Warrad, L., \& Al Omari, R. (2015). The impact of turnover ratios on Jordanian services sectors' performance. Journal of Modern
Accounting and Auditing, 11(2), 7785.

Wirahadi Ahmad, A., \& Septriani, Y. (2008). Konflik Keagenan: Tinjauan Teoritis dan Cara Menguranginya. Jurnal Akuntansi \& Manajemen, 3(2), 47-55.

Wulantika, N., Hariyanto, D., \& Safitri, H. (2018). Pengaruh Current Ratio, Return on Equity dan Market to Book Ratio Terhadap Harga Saham. Jurnal Produktivitas: Jurnal Fakultas Ekonomi Universitas Muhammadiyah Pontianak, $5(1)$. http://dx.doi.org/10.29406/jpr.v5i1.1 246

Yulius, R., Santosa, P. I., \& Hartanto, R. (2016). Efek moderasi kesukarelaan terhadap pembelajaran online pada Universitas Sahid Surakarta. Jurnal Ipteks Terapan, 10(4), 218-224. https://doi.org/10.22216/jit.2016.v10 i4.534

Yulius, Y. (2016). Peranan desain komunikasi visual sebagai pendukung media promosi kesehatan. Besaung: Jurnal Seni Desain Dan Budaya, 1(2). http://dx.doi.org/10.36982/jsdb.v1i2. 132

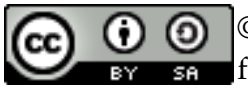
2021 by the authors. Submitted for possible open access publication under the terms and conditions of the Creative Commons Attribution (CC BY SA) license (https://creativecommons.org/licenses/by-sa/4.0/). 